\title{
Influence of composition and multilayer architecture on electrical conductivity of high temperature Pt-alloy films
}

\author{
David J. Frankel, ${ }^{1}$ Scott C. Moulzolf, ${ }^{1}$ Mauricio Pereira da Cunha, ${ }^{1,2}$ Robert J. Lad ${ }^{1,3, \S}$ \\ ${ }^{1}$ Laboratory for Surface Science \& Technology, ${ }^{2}$ Department of Electrical \\ \& Computer Engineering, ${ }^{3}$ Department of Physics \& Astronomy, \\ University of Maine, Orono, ME 04469-5708, USA
}

\begin{abstract}
A multilayer film architecture has been investigated as a means to stabilize the morphology and electrical conductivity of Pt-based nanocomposite films that are exposed to temperatures up to $1200^{\circ} \mathrm{C}$ in air. The multilayer architecture consists of a $150 \mathrm{~nm}$ thick conducting Pt-alloy electrode inserted between a $10 \mathrm{~nm}$ thick adhesion layer and a $50 \mathrm{~nm}$ thick protective capping layer on sapphire or langasite substrates. The Pt-alloy films were fabricated by e-beam co-evaporation of a $\mathrm{Pt}$ or $\mathrm{Pt}_{83} \mathrm{Rh}_{17}$ source and a range of different alloying elements $(\mathrm{Co}$, $\mathrm{Ni}, \mathrm{Cr}, \mathrm{Rh}, \mathrm{Ta}, \mathrm{Ti}, \mathrm{Nb}, \mathrm{Al}, \mathrm{Sn})$ or oxides $\left(\mathrm{HfO}_{2}, \mathrm{ZrO}_{2}, \mathrm{Nb}_{2} \mathrm{O}_{3}, \mathrm{Y}_{2} \mathrm{O}_{3}, \mathrm{RuO}_{2}, \mathrm{CeO}_{2}, \mathrm{NiO}, \mathrm{CoO}\right.$, $\mathrm{MnO}_{2}$ ). Second phase inclusions or interlayers within the Pt-alloy films provide grain boundary pinning and hinder agglomeration of Pt grains, resulting in films that retain conductivities $>$ $1 \times 10^{6} \mathrm{~S} / \mathrm{m}$ after annealing in air. $\mathrm{Pt}-\mathrm{Al}_{2} \mathrm{O}_{3}, \mathrm{Pt}-\mathrm{HfO}_{2}$, and nanolaminate Pt-Ni/Pt-Zr films performed the best, remaining conductive after annealing to $1050-1150^{\circ} \mathrm{C}$. For $\mathrm{Pt}-\mathrm{Rh} / \mathrm{HfO}_{2}$ films, adhesion layers of $\mathrm{Ni}, \mathrm{Zr}, \mathrm{Y}$, and $\mathrm{CeO}_{\mathrm{x}}$ yielded the highest film stability temperature. Capping layers of $\mathrm{ZrO}_{2}$ or $\mathrm{Y}_{2} \mathrm{O}_{3}$ did not significantly improve the film stability. Electrically conducting films that remain stable above $1000^{\circ} \mathrm{C}$ in oxidizing high temperature environments have potential applications as electrodes in a wide range of technologies, including microwave acoustic sensors, MEMS devices, and fuel cells.

${ }^{\S}$ Corresponding author
\end{abstract}

\section{Keywords:}

multilayer films; thin film electrodes; platinum alloys; high temperature; electrical conductivity 


\section{INTRODUCTION}

Many technologies require thin film electrodes that can either operate or be processed at high temperatures $\left(500-1200^{\circ} \mathrm{C}\right)$. Examples include wireless microwave acoustic harsh environment temperature sensors [1,2], gate electrodes for advanced CMOS devices [3,4], SiC electronics [5,6], MEMS micro-thrusters [7] micro-reactors [8,9], micro-hotplates [10-12], thin film anemometers [13,14], thin film thermocouples [15], thin film solid oxide fuel cell devices [16,17], and micro light sources for IR chemical analysis systems [18,19]. Although thick film materials can be used at these temperatures, in most applications the film thickness cannot exceed a few hundred nanometers and stable thin film materials are lacking. Strategies to stabilize thick ( few to $100 \mu \mathrm{m}$ ) films, such as the use of protective scale layers, are not successful when applied to thinner films. Furthermore, when heated to high temperature, thin metallic films tend to agglomerate into isolated islands or undergo oxidation reactions, which lead to insulating behavior and device failure. Other failure modes include evaporation of the film itself or film oxidation and evaporation of volatile oxides. Thus, identification of thin film materials that can maintain high electrical conductivity, particularly above $1000^{\circ} \mathrm{C}$ in the presence of oxygen, remains a challenge.

In previous work [1,20-23], it has been shown that two different strategies for manipulating the structure of Pt-based thin film electrodes can extend their operating range up to near $1000^{\circ} \mathrm{C}$. In one method, shown in Figure 1(a), the Pt-alloy electrode layer is deposited with a second phase material, such as $\mathrm{ZrO}_{2}$, which provides grain boundary pinning and stabilization of a connected network of conducting Pt grains. In a second method, Figure 1(b), thin nanolaminate interlayers such as $\mathrm{Zr}, \mathrm{ZrO}_{2}, \mathrm{HfO}_{2}$, or $\mathrm{ZrB}_{2}$ are used to break up the structure of the electrode layer and retard agglomeration.

In addition to the nanostructured electrode film, an adhesion layer is required to avoid delamination of the electrode layer from the substrate. Effective adhesion layers are typically 
formed by using a metal with high reactivity that forms a chemical bond with the insulating substrate (usually a metal oxide) and forms a strong metal-metal (alloy) bond with Pt alloys, as well as forms stable oxides when heated in air at high temperatures. This layer can also provide other benefits, such as reducing film stress by mediating the coefficient of thermal expansion (CTE) mismatch between the substrate and electrode material. The adhesion layer can influence the interfacial energy at the buried electrode interface, thus modifying the agglomeration behavior. In the absence of an additional interfacial barrier layer, the adhesion layer can also act to retard diffusion of substrate atoms into the electrode layer.

Further measures that can be taken to improve high temperature film performance include the addition of an interfacial barrier layer and a capping layer [22-24]. The interfacial layer can reduce degradation of the electrode layer caused by interdiffusion effects and reaction with the substrate. In experiments that highlighted the importance of the interfacial layer, the same electrode layer was grown on different substrates and then furnace tested to failure [22]. Films grown on stable oxide substrates such as sapphire and quartz remain conductive to higher temperatures than films grown on langasite ( $\mathrm{LGS}-\mathrm{La}_{3} \mathrm{Ga}_{5} \mathrm{SiO}_{14}$ ) and langatate (LGT $\left.\mathrm{La}_{3} \mathrm{Ga}_{5.5} \mathrm{Ta}_{0.5} \mathrm{O}_{14}\right)$ crystals. The results also showed that an $\mathrm{Al}_{2} \mathrm{O}_{3}$ interfacial layer grown by an ALD process helps reduce interdiffusion and reaction at the electrode-substrate interface at high temperature. In addition, the use of a capping layer can alter the free energy balance that drives the agglomeration process, impede high temperature electrode oxidation in air, and provide mechanical protection. Both $\mathrm{SiAlON}$ and $\mathrm{Al}_{2} \mathrm{O}_{3}$ capping layers have been shown to increase the maximum temperature at which electrode films remain conducting and morphologically stable, although $\mathrm{Al}_{2} \mathrm{O}_{3}$ layers have been shown to be more effective [22-24].

In this paper, results of annealing experiments are reported for a large number of prospective nanocomposite thin film materials that embed either pinning inclusions or pinning interlayers into a Pt-alloy conducting electrode nanostructure. Several thin film materials are 
investigated up to $1200^{\circ} \mathrm{C}$ in air for use as the Pt-alloy conducting electrode, the pinning additive in the electrode layer, the adhesion layer, and the protective capping layer.

\section{EXPERIMENTAL}

Platinum-alloy films were deposited onto $0.5 \mathrm{~mm}$ thick epitaxially polished langasite $\left(\mathrm{La}_{3} \mathrm{Ga}_{5} \mathrm{SiO}_{14}\right)$ or $\mathrm{r}$-sapphire $\left(\alpha-\mathrm{Al}_{2} \mathrm{O}_{3}\right)$ wafers having $<2 \mathrm{~nm}$ rms roughness. The depositions were carried out at room temperature in an ultra-high vacuum chamber with typical base pressure $<10^{-7} \mathrm{~Pa}$. The thin film materials were deposited using electron-beam evaporation of $\geq 99.9 \%$ purity metal sources (Pt, Mn, Ni, $\mathrm{CeO}_{x}, \mathrm{Zr}, \mathrm{Nb}, \mathrm{Cr}, \mathrm{Hf}, \mathrm{Y}, \mathrm{Ti}, \mathrm{Ta}, \mathrm{Al}, \mathrm{Sn}, \mathrm{Ru}, \mathrm{Co}$ ) either in vacuum $\left(\sim 1 \times 10^{-7} \mathrm{~Pa}\right)$ or in 5.0 grade $\mathrm{O}_{2}$ gas $\left(\sim 2.7 \times 10^{-3} \mathrm{~Pa}\right)$, depending on whether a Pt-metal or Pt-metal oxide film composition was grown. Since the total oxygen content in the films depended on the reactivity of the particular metals used, only the nominal Pt and metal content (atomic \%) is reported for films deposited in the presence of $\mathrm{O}_{2}$ gas. Pt-Rh films were deposited by e-beam evaporating a $\mathrm{Pt90 \% -Rh10 \%}$ by weight alloy charge, which corresponds to a $\mathrm{Pt}_{83} \mathrm{Rh}_{17}$ alloy composition using atomic $\%$ as quoted for the other alloys in this study. All the other Pt-alloys

were formed via co-evaporation from single element sources. The deposition chamber was equipped with two four-pocket e-beam evaporators, which enabled co-deposition of two materials and also facilitated changing of deposition material without breaking vacuum when growing multi-layered structures.

Quartz crystal deposition rate monitors (QCMs) were located both at the sample plane and in positions near the e-beam sources to monitor them independently. Tooling factors were determined by depositing single element films and comparing QCM thicknesses at each location. Film densities for each alloy material were determined by using the measured tooling factor to deposit nominally $50 \mathrm{~nm}$ thick films onto polished fused silica substrates with a shadow mask defining a $0.25 \mathrm{~mm}$ stripe, and measuring the stripe thickness with a stylus profilometer. Tabulated values of the Z-ratio for the QCMs were used for all depositions. For co-deposited 
materials, film composition and thickness were controlled by adjusting the e-beam power levels, based on rate measurements using each respective QCM head with the appropriate calibrated tooling and density values. In situ XPS analysis was also used to verify the average as-deposited film compositions. The adhesion layers were deposited onto the sapphire or langasite substrates via e-beam evaporation to a nominal thickness of $10 \mathrm{~nm}$, and subsequent electrode layers were immediately deposited to their desired thickness, which were typically within $\pm 10 \%$ of their targeted value of $150 \mathrm{~nm}$, as measured by stylus profilometry. Capping layers of $50 \mathrm{~nm}$ thickness were deposited by e-beam evaporation in the presence of $2.7 \times 10^{-3} \mathrm{~Pa} \mathrm{O}_{2}$.

Following film deposition, samples were diced to dimensions of $3 \mathrm{~mm} \times 6.5 \mathrm{~mm}$ for furnace heating and conductivity measurements. The large number of candidate electrode materials explored in this study was screened by determining the maximum temperature to which blanket-deposited thin films remained electrically conductive. At temperatures above $800^{\circ} \mathrm{C}$, rapid solid state diffusion can induce compositional changes near the interface between a bond wire and a film, which can lead to bond deterioration and loss of electrical connection as well as changes in the properties of the neighboring electrode film [25]. In order to efficiently and accurately screen large numbers of samples at temperatures up to $1200^{\circ} \mathrm{C}$, an alternative non-wire bonding method was employed in which multiple blanket deposited samples were simultaneously heated within a tube furnace at $800,900,1000,1050,1100,1150$, and $1200^{\circ} \mathrm{C}$ by precisely positioning them on a sample fixture that spanned the temperature gradient within the tube furnace. All annealing treatments were the same, and consisted of a $10^{\circ} \mathrm{C} / \mathrm{s} \mathrm{ramp}$ from $25^{\circ} \mathrm{C}$ to the desired temperature for a 4 hour hold, followed by cooling to room temperature. Following this heating cycle, 4-point conductivity measurements were made at room temperature on all samples and selected samples were imaged using a Zeiss NVision 40 cross beam FIB/SEM instrument. To screen the large number of film configurations, room temperature 4-point conductivity 
measurements were compared since these values are a function of the high temperature film nanostructure and are a good measure of relative film stability. Using this method, up to four different types of blanket film samples were evaluated over the range $800-1200^{\circ} \mathrm{C}$ during one experimental run with no danger of artifacts due to bonding of connecting wires.

\section{RESULTS AND DISCUSSION}

\subsection{Adhesion Layer Studies}

Seven different materials $\left(\mathrm{Mn}, \mathrm{CeO}_{\mathrm{x}}, \mathrm{Ni}, \mathrm{Cr}, \mathrm{Nb}, \mathrm{Hf}, \mathrm{Y}\right)$ were identified and tested as the $10 \mathrm{~nm}$ adhesion layer under a $150 \mathrm{~nm}$ thick $\mathrm{Pt}_{83} \mathrm{Rh}_{17} / \mathrm{HfO}_{2}$ electrode film, and compared to the performance of the same $\mathrm{Pt}_{83} \mathrm{Rh}_{17} / \mathrm{HfO}_{2}$ film but with a $\mathrm{Zr}$ adhesion layer as reported previously [23]. $\mathrm{Mn}, \mathrm{Ni}$, and $\mathrm{CeO}_{\mathrm{x}}$ were tested on sapphire substrates, and $\mathrm{Cr}, \mathrm{Nb}, \mathrm{Hf}$, and $\mathrm{Y}$ tested on langasite substrates. Figure 2 shows conductivity results for $\mathrm{Pt}_{83} \mathrm{Rh}_{17} / \mathrm{HfO}_{2}$ films after annealing for 4 hours in air at each temperature. Films with adhesion layers of $\mathrm{Cr}$ or $\mathrm{Nb}$ on langasite, and $\mathrm{Mn}$ on sapphire, failed at a $50^{\circ} \mathrm{C}$ lower temperature than films with $\mathrm{Zr}$ adhesion layers, whereas films with $\mathrm{Hf}, \mathrm{Y}$, or $\mathrm{CeO}_{\mathrm{x}}$ adhesion layers maintained conductivity to the same temperature. Compared to films with $\mathrm{Zr}$ adhesion layers, following heating to $1050^{\circ} \mathrm{C}$, films with $\mathrm{Hf}$ had lower conductivity, films with $\mathrm{Y}$ had nearly the same conductivity and films with $\mathrm{CeO}_{\mathrm{x}}$ had somewhat higher conductivity. In all cases, the adhesion layer became oxidized during the high temperature annealing, and the failure temperature correlates with different degrees of agglomeration caused by each adhesion layer material. Overall, the best performing adhesion layer was $\mathrm{Ni}$, which on a sapphire substrate yielded a $\mathrm{Pt}_{83} \mathrm{Rh}_{17} / \mathrm{HfO}_{2}$ film that remained conductive after heating to $1100^{\circ} \mathrm{C}$, which is $50^{\circ} \mathrm{C}$ higher than for any other adhesion layer.

\subsection{Platinum Alloy Studies}

$\mathrm{Pt}-\mathrm{Rh}$ alloy thin films have been demonstrated to have superior stability compared to pure $\mathrm{Pt}$ and Pt-Au alloy films [20]. In this section, high temperature testing results are reported for a number of other Pt-alloy films. It has been reported that the high temperature oxidation of bulk 
Pt-alloys with small additions of $\mathrm{Ti}, \mathrm{Nb}$, and $\mathrm{Ta}$ produce weight gain during heating in air at $1300^{\circ} \mathrm{C}$ due to oxidation [26]. As most alloys lose weight at these temperatures due to loss of volatile platinum oxide, these alloys were considered as good candidates for the thin film Pt-alloy electrodes. In addition, both $\mathrm{Ta}$ and $\mathrm{Nb}$ have melting points significantly higher than $\mathrm{Rh}$. The atomic percentage of the second component that was incorporated into these films followed those suggested in the literature: $6 \% \mathrm{Ti}, 4 \% \mathrm{Ta}$, and $15 \% \mathrm{Nb}$. Cobalt is used as a grain refiner in bulk platinum alloys suggesting that Co additions could slow agglomeration in alloy films by inhibiting grain growth. Platinum aluminides are used for corrosion resistant coatings and alumina is a very stable high temperature ceramic. Other elements were chosen based on their use in high temperature alloys, high melting points or presence of stable oxides.

The Pt-alloy films were grown by co-depositing Pt with: Ti, Ta, Nb, Al, Ru, Sn on langasite substrates, and $\mathrm{Co}, \mathrm{Cr}, \mathrm{Ni}, \mathrm{Si}$ on sapphire substrates; in all cases, a $\mathrm{Zr}$ adhesion layer was used. Figure 3 shows the results of conductivity measurements following 4 hour annealing treatments in air, along with data for a pure $\mathrm{Pt}$ and $\mathrm{Pt}_{83} \mathrm{Rh}_{17}$ film for reference. The $\mathrm{Pt}_{50} \mathrm{Si}_{50}$ and $\mathrm{Pt}_{83} \mathrm{Ru}_{17}$ films failed after initially heating to $800^{\circ} \mathrm{C}$ and are not shown in the figures. The $\mathrm{Pt}_{86} \mathrm{Al}_{14}$ film was the best film and remained conductive to $1100^{\circ} \mathrm{C}$ on langasite. $\mathrm{The} \mathrm{Pt}_{85} \mathrm{Nb}_{15}$, $\mathrm{Pt}_{80} \mathrm{Sn}_{20}$, and $\mathrm{Pt}_{85} \mathrm{Co}_{15}$ alloy films show promise, having survived to temperatures equal to or higher than the reference $\mathrm{Pt}_{83} \mathrm{Rh}_{17}$ film. The $\mathrm{Pt}_{85} \mathrm{Co}_{15}$ and $\mathrm{Pt}_{90} \mathrm{Ni}_{10}$ alloys deposited on sapphire had the same maximum survival temperature as $\mathrm{Pt}_{83} \mathrm{Rh}_{17}$ on langasite, with the additional benefit of higher conductivity. Increasing the $\mathrm{Ni}$ content up to $\mathrm{Pt}_{70} \mathrm{Ni}_{30}$ extended the film operational temperature range, although film conductivity was reduced by about a factor of two. Films that did not perform as well as the reference $\mathrm{Pt}_{83} \mathrm{Rh}_{17}$ film, failing after heating at $900^{\circ} \mathrm{C}$, included $\mathrm{Pt}_{90} \mathrm{Cr}_{10}, \mathrm{Pt}_{94} \mathrm{Ti}_{6}$ and $\mathrm{Pt}_{96} \mathrm{Ta}_{4}$ as well as the pure $\mathrm{Pt}$ film.

Secondary electron images that elucidate the differences in film morphology of the $\mathrm{Pt}_{85} \mathrm{Nb}_{15}, \mathrm{Pt}_{83} \mathrm{Rh}_{17}$, and $\mathrm{Pt}_{96} \mathrm{Ta}_{4}$ films after annealing in air for 4 hours at $1000^{\circ} \mathrm{C}$ are shown in 
Figure 4. The films have agglomerated to different degrees, with the $\mathrm{Pt}_{85} \mathrm{Nb}_{15}$ film having the smallest interconnected Pt-rich grain network. Both the $\mathrm{Pt}_{83} \mathrm{Rh}_{17}$ and $\mathrm{Pt}_{96} \mathrm{Ta}_{4}$ films show isolated agglomerated grains, with the highest degree of agglomeration for $\mathrm{Pt}_{96} \mathrm{Ta}_{4}$, consistent with the electrical characterization results.

Since the $\mathrm{Pt}_{86} \mathrm{Al}_{14}$ film out-performed the other alloy films tested in Figure 3, additional Pt-Al films were grown to determine the effect of varying the Al content and also study the influence of introducing $\mathrm{O}_{2}$ in the deposition chamber to form oxide or sub-oxide phases during growth. Figure 5 shows conductivity results for a series of Pt-Al alloy film compositions grown on sapphire substrates with a $\mathrm{Zr}$ adhesion layer. The films designated $\mathrm{Pt}-\mathrm{Al}_{2} \mathrm{O}_{3}$ were grown in $2.7 \times 10^{-3} \mathrm{~Pa} \mathrm{O}_{2}$, whereas those designated Pt-Al were grown in ultra-high vacuum. The best performance was obtained from the $\mathrm{Pt}_{86}-\mathrm{Al}, \mathrm{Pt}_{86}-\mathrm{Al}_{2} \mathrm{O}_{3}$, and $\mathrm{Pt}_{72}-\mathrm{Al}_{2} \mathrm{O}_{3}$ films, which remained conductive upon heating to $1150^{\circ} \mathrm{C}$ for 4 hours. The fact that the $\mathrm{Pt}_{86}-\mathrm{Al}$ and $\mathrm{Pt}_{86}-\mathrm{Al}_{2} \mathrm{O}_{3}$ gave very similar results gives evidence that the metallic $\mathrm{Al}$ and $\mathrm{Al}$ sub-oxide components in the films become fully oxidized during high temperature air oxidation, yielding the same film nanostructure of $\mathrm{Al}_{2} \mathrm{O}_{3}$ pinning inclusions that stabilize the $\mathrm{Pt}$ grains. Films with higher $\mathrm{Pt}$ content $(93 \%)$ only maintained conductivity to $1050^{\circ} \mathrm{C}$, indicating that the $\mathrm{Al}$ content of these films was too low to effectively hinder Pt agglomeration.

To observe possible substrate effects, a $\mathrm{Pt}_{86} \mathrm{Al}_{14}$ film was grown on a langasite substrate and both $\mathrm{Pt}_{86}-\mathrm{Al}$ and $\mathrm{Pt}_{86}-\mathrm{Al}_{2} \mathrm{O}_{3}$ films were grown on a langasite substrate coated with a $50 \mathrm{~nm}$ thick $\mathrm{Al}_{2} \mathrm{O}_{3}$ interfacial barrier grown in an atomic layer deposition (ALD) reactor; all samples included a $\mathrm{Zr}$ adhesion layer and the two $\mathrm{Pt}_{86}-\mathrm{Al}$ electrode films were grown in the same deposition run. $\mathrm{Up}$ to $1000^{\circ} \mathrm{C}$, the $\mathrm{Pt}_{86}-\mathrm{Al}$ film grown on $\mathrm{ALD} \mathrm{Al}_{2} \mathrm{O}_{3}$ had values of conductivity very close to the $\mathrm{Pt}_{86}-\mathrm{Al}$ film without the $\mathrm{ALD} \mathrm{Al}_{2} \mathrm{O}_{3}$ layer. Above $1000^{\circ} \mathrm{C}$, the film with the extra interfacial layer maintained higher conductivity than the sample without the interfacial $\mathrm{Al}_{2} \mathrm{O}_{3}$ layer, but both failed at the same temperature of $1150^{\circ} \mathrm{C}$. The $\mathrm{Pt}_{86}-\mathrm{Al}_{2} \mathrm{O}_{3}$ film grown on 
$\mathrm{Al}_{2} \mathrm{O}_{3}$-coated langasite performed very similarly to films of the same composition grown on sapphire substrates, and also similar to the $\mathrm{Pt}_{86}-\mathrm{Al}_{14}$ film grown on $\mathrm{ALD} \mathrm{Al}_{2} \mathrm{O}_{3}$, which did not fail until heating to $1150^{\circ} \mathrm{C}$. These results suggest that the langasite substrate does not significantly increase film degradation at lower temperatures, and that the $\mathrm{ALD} \mathrm{Al}_{2} \mathrm{O}_{3}$ interfacial barrier layer is beneficial when heating samples above $1000^{\circ} \mathrm{C}$.

Figure 6 shows SEM images that illustrate the influence of varying the $\mathrm{Pt}-\mathrm{Al}_{2} \mathrm{O}_{3}$ composition on the film nanostructure. Following heating to $1050^{\circ} \mathrm{C}$, the $\mathrm{Pt}_{93}-\mathrm{Al}_{2} \mathrm{O}_{3}$ film with the lowest $\mathrm{Al}_{2} \mathrm{O}_{3}$ content has agglomerated into isolated islands as shown in Figure 6(a), consistent with zero film conductivity at this temperature. There is evidently an insufficient amount of $\mathrm{Al}_{2} \mathrm{O}_{3}$ present to induce grain boundary drag and hence prevent agglomeration. After heating films with higher $\mathrm{Al}_{2} \mathrm{O}_{3}$ content $\left(\mathrm{Pt}_{86}-\mathrm{Al}_{2} \mathrm{O}_{3}\right.$ and $\left.\mathrm{Pt}_{72}-\mathrm{Al}_{2} \mathrm{O}_{3}\right)$ to $1100^{\circ} \mathrm{C}$, holes form in the conducting Pt-alloy phase due to areas of dewetting, as shown in Figures 6(b) and 6(c), but both films remain continuous. The $\mathrm{Pt}_{72}-\mathrm{Al}_{2} \mathrm{O}_{3}$ film (Fig. 6c) shows evidence of a two-phase mixture, possibly due to excess $\mathrm{Al}_{2} \mathrm{O}_{3}$ on the surface. Of particular significance is the absence of any large Pt grains in these films following heating to $1100^{\circ} \mathrm{C}$. In contrast, most other $\mathrm{Pt}$ and $\mathrm{Pt}-\mathrm{Rh}$ alloy films heated above $1000^{\circ} \mathrm{C}$ undergo considerable $\mathrm{Pt}$ grain growth and recrystallization resulting in large crystalline grains.

\subsection{Pinning Material Studies}

The effect of using different types of metal oxide inclusions for grain boundary pinning and high temperature stabilization of $\mathrm{Pt}_{83} \mathrm{Rh}_{17}$ films was studied. Previous work has shown that incorporating $\mathrm{ZrO}_{2}$ into $\mathrm{Pt}_{83} \mathrm{Rh}_{17}$ films at levels corresponding to $10-28$ atomic \% $\mathrm{Zr}$ as determined by XPS, can extend the conducting range of $\mathrm{Pt}_{83} \mathrm{Rh}_{17}$ films up to $1000^{\circ} \mathrm{C}$ via formation of $\mathrm{ZrO}_{2}$ inclusions that help stabilize the film morphology [24] . Based on these results, a ratio of the pinning metal concentration to Pt concentration of $27 \%$ was targeted in the present work. Figure 7(a) shows the conductivity results for seven prospective pinning materials: $\mathrm{MnO}_{2}$, 
$\mathrm{CeO}_{2}, \mathrm{NiO}, \mathrm{HfO}_{2}, \mathrm{CoO}, \mathrm{Al}$, and $\mathrm{ZrC}$ added to $\mathrm{Pt}_{83} \mathrm{Rh}_{17}$ films on sapphire substrates. In addition, four prospective oxide pinning materials: $\mathrm{HfO}_{2}, \mathrm{Y}_{2} \mathrm{O}_{3}, \mathrm{Nb}_{2} \mathrm{O}_{3}$, and $\mathrm{RuO}_{2}$ were tested on langasite substrates and compared to $\mathrm{ZrO}_{2}, \mathrm{Zr}$, and no pinning phases after annealing up to $1200^{\circ} \mathrm{C}$ as shown in Figure $7(\mathrm{~b})$. Except for $\mathrm{ZrC}, \mathrm{Zr}$, and $\mathrm{Al}$, the films were grown in a $2.7 \times 10^{-3} \mathrm{~Pa}$ background of $\mathrm{O}_{2}$ to create oxide pinning phases during the deposition; subsequent air annealing caused the pinning metal components in all the films to reach their maximal valence oxide state.

On sapphire substrates, $\mathrm{HfO}_{2}$ proved to be the best pinning additive, with the film remaining conductive up to $1150^{\circ} \mathrm{C}$, which is $50^{\circ} \mathrm{C}$ higher than the same film on a langasite substrate. Films with $\mathrm{Al}$ and $\mathrm{MnO}_{2}$ failed at a $50^{\circ} \mathrm{C}$ lower temperature than the film with $\mathrm{HfO}_{2}$, with performance similar to films with $\mathrm{ZrO}_{2}$ as a pinning additive. Interestingly, the $\mathrm{Pt}_{83} \mathrm{Rh}_{17}-\mathrm{Al}$ film in these tests did not perform as well as the $\mathrm{Pt} / \mathrm{Al}_{2} \mathrm{O}_{3}$ films discussed in Section 3.2. The presence of $\mathrm{Rh}$ is evidently associated with the earlier failure of the $\mathrm{Pt}_{83} \mathrm{Rh}_{17}-\mathrm{Al}$ film. The film with $\mathrm{CeO}_{2}$ as an additive failed after heating at $1050^{\circ} \mathrm{C}$, and films with $\mathrm{ZrC}, \mathrm{CoO}$ and $\mathrm{NiO}$ inclusions did not perform as well, failing after heating at $1000^{\circ} \mathrm{C}$. Although carbides are attractive due to their high temperature performance and alternate chemistry as opposed to oxides, the sample with $\mathrm{ZrC}$ as a pinning material was only conductive to $900^{\circ} \mathrm{C}$, possibly due to oxidation of the $\mathrm{ZrC}$ phase at higher temperatures.

On langasite substrates, the $\mathrm{Pt}_{83} \mathrm{Rh}_{17}$ film with no pinning additives, labeled 'None' in Figure $7(\mathrm{~b})$, was conductive after heating to $900^{\circ} \mathrm{C}$ and failed after heating to $1000^{\circ} \mathrm{C}$, whereas the $\mathrm{Pt}_{83} \mathrm{Rh}_{17}-\mathrm{ZrO}_{2}$ reference material remained conductive after heating to $1000^{\circ} \mathrm{C}$ and failed after heating at $1050^{\circ} \mathrm{C}$, consistent with previous work [23]. Co-deposition of $\mathrm{Zr}$ in the absence of oxygen resulted in a film that performed very similar to a film co-deposited with $\mathrm{Zr}$ in a $2.7 \times 10^{-3}$ $\mathrm{Pa} \mathrm{O}_{2}$ background pressure, again signifying that inclusions of the maximum valence oxide, $\mathrm{ZrO}_{2}$, are formed during the high temperature air anneal. Results from other films deposited on langasite substrates indicate that (i) films with $\mathrm{Nb}_{2} \mathrm{O}_{3}$ and $\mathrm{RuO}_{2}$ are inferior compared to samples 
containing $\mathrm{ZrO}_{2}$, (ii) films with $\mathrm{Y}_{2} \mathrm{O}_{3}$ have a similar failure temperature and somewhat higher conductivity, and (iii) films with $\mathrm{HfO}_{2}$ have a higher survival temperature by approximately $50^{\circ} \mathrm{C}$. Replacement of $\mathrm{Zr}$ by $\mathrm{Ru}$ caused the film to fail at $1000^{\circ} \mathrm{C}$, likely due to the higher vapor pressure of $\mathrm{RuO}_{2}$. Niobium has atomic number that is one larger than $\mathrm{Zr}$ and a higher melting point, but use of $\mathrm{Nb}_{2} \mathrm{O}_{3}$ as a pinning material also resulted in failure at $1000^{\circ} \mathrm{C}$. Yttrium has an atomic number one lower that $\mathrm{Zr}$, and $\mathrm{Y}_{2} \mathrm{O}_{3}$ has been used for pinning in bulk Pt-based materials and phase stabilization of zirconia. Use of $\mathrm{Y}_{2} \mathrm{O}_{3}$ resulted in higher conductivity at $900^{\circ} \mathrm{C}$ and $1000^{\circ} \mathrm{C}$, but did not extend the survivability to higher temperatures. Hafnium has very similar chemical properties to $\mathrm{Zr}$, but twice the mass and hence lower atomic mobility. The replacement of $\mathrm{Zr}$ with $\mathrm{Hf}$ resulted in increased film conductivity at $900^{\circ} \mathrm{C}$ and $1000^{\circ} \mathrm{C}$ and a $50^{\circ} \mathrm{C}$ increase in the maximum temperature at which the film remained conducting.

Experiments were performed to determine if adding a grain boundary pinning mechanism to Pt-Co and Pt-Ni films would extend their operational temperature range. Because the deposition system can only co-evaporate two materials at a time, the film architecture of Figure 1(b) was used. Thin, $7.5 \mathrm{~nm}$ interlayers of Pt co-deposited with $\mathrm{Zr}$ were interleaved with $27.5 \mathrm{~nm}$ thick layers of co-evaporated Pt-Co or Pt-Ni, for a total stack of 8 layers grown on sapphire substrates. A Pt-Co or Pt-Ni layer was deposited directly over the $\mathrm{Zr}$ adhesion layer and the stack was terminated with $\mathrm{Pt}-\mathrm{Zr}$ as the top layer. The conductivity results after furnace testing of these two film types are shown in Figure 8 . The $\mathrm{Pt}_{85} \mathrm{Co}_{15} / \mathrm{Pt}_{84} \mathrm{Zr}_{16}$ nanolaminate film with a 11:3 layer ratio remained conductive after heating to $1100^{\circ} \mathrm{C}$ and the $\mathrm{Pt}_{90} \mathrm{Ni}_{10} / \mathrm{Pt}_{84} \mathrm{Zr}_{16}$ nanolaminate film survived to $1150^{\circ} \mathrm{C}$.

Additional Pt-Ni and Pt-Co nanolaminate films were grown to explore the effect of changing the interlayer thickness ratio and the $\mathrm{Pt}-\mathrm{Ni}$ composition ratio. $\mathrm{A} \mathrm{Pt}_{70} \mathrm{Ni}_{30} / \mathrm{Pt}_{84} \mathrm{Zr}_{16}$ nanolaminate film with a 1:1 interlayer ratio and $17.5 \mathrm{~nm}$ nominal layer thickness performed in a 
nearly identical manner as a film with a 11:3 thickness ratio and $\mathrm{Pt}_{90} \mathrm{Ni}_{10}$ composition. The $\mathrm{Pt}_{70} \mathrm{Ni}_{30}$ film was expected to outperform the $\mathrm{Pt}_{90} \mathrm{Ni}_{10}$ film given the results shown in Figure 3, but the nearly equivalent performance suggests that a 1:1 interlayer ratio is less effective. Figure 8 also shows the effect of adding $\mathrm{O}_{2}$ to the growth chamber for a similar 1:1 thickness ratio film (+). The creation of Ni-oxides in the as-deposited film was highly detrimental, in contrast to Pt$\mathrm{Al}_{2} \mathrm{O}_{3}$ films where the addition of $\mathrm{O}_{2}$ was found to improve the film operational temperature and film reproducibility. Not shown in Figure 8 is a Pt-Ni-based film with Pt-Al pinning layers deposited in the same manner as described above. Testing indicated the Pt-Al interlayers do not work as well as Pt-Zr interlayers with Pt-Ni-based films. Figure 8 also shows the effect of adding an $\mathrm{ALD} \mathrm{Al}_{2} \mathrm{O}_{3}$ capping layer, as discussed in the next section.

SEM imaging of the Pt-Ni and Pt-Co nanolaminate films after heating at $1100^{\circ} \mathrm{C}$ (Figure 9) shows very similar morphology, with larger Pt crystallites appearing in the Co containing film. Based on the Z-contrast in the backscattered electron images as well as EDS analysis, the bright areas are $\mathrm{Pt}$-rich with no detected $\mathrm{Ni}$ or $\mathrm{Co}$, the small dark regions are $\mathrm{ZrO}_{2}$ precipitates, and the dewetted regions contain primarily $\mathrm{Ni}$ or Co atoms.

\subsection{Capping Layer Studies}

Capping layers are useful for mechanically protecting the underlying electrode film and also for potentially extending the operating temperature range by retarding film agglomeration and acting as a diffusion barrier to isolate the electrode film from oxygen or other reactive gases. Capping layer studies were performed on $\mathrm{Pt}_{83} \mathrm{Rh}_{17}-\mathrm{ZrO}_{2}$ electrode films by investigating the effects of adding a nominally $50 \mathrm{~nm}$ thick $\mathrm{Y}_{2} \mathrm{O}_{3}$ or $\mathrm{ZrO}_{2}$ capping layer. In both cases, the additional capping layer resulted in improved conductivity after heating to $1000^{\circ} \mathrm{C}$, with the $\mathrm{Y}_{2} \mathrm{O}_{3}$ capping layer showing the better performance. After heating to $1050^{\circ} \mathrm{C}$ for 4 hours, both the uncapped and $\mathrm{ZrO}_{2}$ capped films were no longer conductive while the $\mathrm{Y}_{2} \mathrm{O}_{3}$ capped film exhibited very low but non-zero conductivity. As previously reported [23], depositing an $\mathrm{Al}_{2} \mathrm{O}_{3}$ 
capping layer via $\mathrm{ALD}$ onto a $\mathrm{Pt}_{83} \mathrm{Rh}_{17}-\mathrm{HfO}_{2}$ film increases film conductivity following annealing to $1100^{\circ} \mathrm{C}$ by nearly a factor of five, although the films still fail when heated above $1100^{\circ} \mathrm{C}$. The effect of adding $50 \mathrm{~nm}$ thick $\mathrm{ALD} \mathrm{Al}_{2} \mathrm{O}_{3}$ capping layers onto $\mathrm{Pt}_{90} \mathrm{Ni}_{10} / \mathrm{Pt}_{84} \mathrm{Zr}_{16}$ and $\mathrm{Pt}_{85} \mathrm{Co}_{15} / \mathrm{Pt}_{84} \mathrm{Zr}_{16}$ nanolaminate films is shown in Figure 8. Addition of the $\mathrm{Al}_{2} \mathrm{O}_{3}$ cap resulted in decreased conductivity for the $\mathrm{Pt}-\mathrm{Co} / \mathrm{Pt}-\mathrm{Zr}$ nanolaminate film above $1000^{\circ} \mathrm{C}$, whereas the conductivity of a Pt-Ni/Pt-Zr nanolaminate film was significantly improved with the addition of the cap.

\section{CONCLUSIONS}

Metallic conducting electrode films tend to either agglomerate into isolated islands or become heavily oxidized at high temperature in air leading to insulating behavior. In this work, a wide range of $150 \mathrm{~nm}$ thick Pt-alloy films containing a dispersed oxide phase $\left(\mathrm{TiO}_{2}, \mathrm{Ta}_{2} \mathrm{O}_{5}\right.$, $\mathrm{Nb}_{2} \mathrm{O}_{3}, \mathrm{Al}_{2} \mathrm{O}_{3}, \mathrm{RuO}_{2}, \mathrm{SnO}_{2}, \mathrm{CoO}, \mathrm{Cr}_{2} \mathrm{O}_{3}, \mathrm{NiO}, \mathrm{SiO}_{2}, \mathrm{ZrO}_{2}, \mathrm{Y}_{2} \mathrm{O}_{3}, \mathrm{HfO}_{2}, \mathrm{CeO}_{2}, \mathrm{MnO}_{2}$ ) were screened for their electrical conductivity after annealing up to $1200^{\circ} \mathrm{C}$ in air. The films were deposited onto sapphire and langasite substrates coated with a $10 \mathrm{~nm}$ thick adhesion layer $(\mathrm{Cr}$, $\mathrm{Nb}, \mathrm{Hf}, \mathrm{Y}, \mathrm{Mn}, \mathrm{Ni}, \mathrm{CeO}_{\mathrm{x}}$ ) using e-beam co-evaporation in both vacuum and in background $\mathrm{O}_{2}$ gas. Following air heat treatments up to $1200^{\circ} \mathrm{C}$, all the metallic components completely oxidized into a second phase oxide that coexist with Pt-rich grains. Layering or adding oxide inclusions provides grain boundary pinning and hinders the agglomeration process to achieve electrical and morphological film stabilization. The best performing electrode films that were tested in this study were $\mathrm{Pt}-\mathrm{Al}_{2} \mathrm{O}_{3}, \mathrm{Pt}-\mathrm{HfO}_{2}$, and $\mathrm{Pt}-\mathrm{Ni} / \mathrm{Pt}-\mathrm{Zr}$ nanolaminate films, which retained conductivity after heating in the $1050-1150^{\circ} \mathrm{C}$ range.

\section{ACKNOWLEDGMENTS}

This work was supported by U.S. Department of Energy Award \#DE-FE0007379TDD. This paper is dedicated to the memory of one of the authors, Scott C. Moulzolf (1971-2013), who 
acquired the majority of data reported in this work, and who for many years contributed immensely to scientific interactions in the Laboratory for Surface Science \& Technology at the University of Maine. Disclaimer: This report was prepared as an account of work sponsored by an agency of the United States Government. Neither the United States Government nor any agency thereof, nor any of their employees, makes any warranty, express or implied, or assumes any legal liability or responsibility for the accuracy, completeness, or usefulness of any information, apparatus, product, or process disclosed, or represents that its use would not infringe privately owned rights. Reference herein to any specific commercial product, process, or service by trade name, trademark, manufacturer, or otherwise does not necessarily constitute or imply its endorsement, recommendation, or favoring by the United States Government or any agency thereof. The views and opinions of authors expressed herein do not necessarily state or reflect those of the United States Government or any agency thereof. 


\section{REFERENCES}

[1] M.P. da Cunha, R.J. Lad, T. Moonlight, G. Bernhardt, D.J. Frankel, in:, 2008 IEEE Ultrason. Symp. Vols 1-4 Append., IEEE, New York, 2008, pp. 205-208.

[2] M.P. da Cunha, R.J. Lad, T. Moonlight, S. Moulzolf, A. Canabal, R. Behanan, P.M. Davulis, D. Frankel, G. Bernhardt, T. Pollard, D.F. McCann, IEEE Sens. 2011 (2011) 614.

[3] X. Zhu, J. Zhu, A. Li, Z. Liu, N. Ming, J. Mater. Sci. Technol. 25 (2009) 289.

[4] E.P. Gusev, V. Narayanan, M.M. Frank, IBM J. Res. Dev. 50 (2006) 387.

[5] G.W. Hunter, P.G. Neudeck, R.S. Okojie, G.M. Beheim, J.A. Powell, L.Y. Chen, J. Turbomach. - Trans. ASME 125 (2003) 658.

[6] R.S. Okojie, D. Lukco, Y.L.L. Chen, D.J. Spry, J. Appl. Phys. 91 (2002) 6553.

[7] N. Miyakawa, W. Legner, T. Ziemann, D. Telitschkin, H.-J. Fecht, A. Friedberger, Microsyst. Technol.-Micro- Nanosyst.-Inf. Storage Process. Syst. 18 (2012) 1077.

[8] S.L. Firebaugh, K.F. Jensen, M.A. Schmidt, J. Microelectromech. Syst. 7 (1998) 128.

[9] R.M. Tiggelaar, R.G.P. Sanders, A.W. Goenland, J.G.E. Gardeniers, Sens. Actuators A 152 (2009) 39.

[10] J. Courbat, D. Briand, N.F. de Rooij, Sens. Actuators - Phys. 142 (2008) 284.

[11] D. Briand, J. Courbat, in:, R. Jaaniso, O.K. Tan (Eds.), Semicond. Gas Sens., Woodhead Publ. Ltd, Cambridge, 2013, pp. 220-260.

[12] S. Semancik, R.E. Cavicchi, M.C. Wheeler, J.E. Tiffany, G.E. Poirier, R.M. Walton, J.S. Suehle, B. Panchapakesan, D.L. DeVoe, Sens. Actuators B - Chem. 77 (2001) 579.

[13] F. Mailly, A. Giani, R. Bonnot, P. Temple-Boyer, F. Pascal-Delannoy, A. Foucaran, A. Boyer, Sens. Actuators - Phys. 94 (2001) 32.

[14] F. Mailly, A. Giani, A. Martinez, R. Bonnot, P. Temple-Boyer, A. Boyer, Sens. Actuators Phys. 103 (2003) 359.

[15] O.J. Gregory, T. You, IEEE Sensors 5 (2005) 833.

[16] H. Huang, M. Nakamura, P. Su, R. Fasching, Y. Saito, F.B. Prinz, J. Electrochem. Soc. 154 (2007) B20.

[17] K. Kerman, B.-K. Lai, S. Ramanathan, J. Power Sources 196 (2011) 2608.

[18] J. Spannhake, O. Schulz, A. Helwig, A. Krenkow, G. Muller, T. Doll, Sensors 6 (2006) 405. 
[19] K.-N. Lee, D.-S. Lee, S.-W. Jung, Y.-H. Jang, Y.-K. Kim, W.-K. Seong, J. Micromechanics Microengineering 19 (2009) 115011.

[20] M.P. da Cunha, T. Moonlight, R. Lad, G. Bernhardt, D.J. Frankel, in:, 2007 IEEE Ultrason. Symp. Proc. Vols 1-6, IEEE, New York, 2007, pp. 2107-2110.

[21] R. Behanan, S.C. Moulzolf, M. Call, G. Bernhardt, D. Frankel, R.J. Lad, M.P. da Cunha, 2013 IEEE Int. Ultrason. Symp. IUS (2013) 1005.

[22] S.C. Moulzolf, D.J. Frankel, M.P. da Cunha, R.J. Lad, Smart Sens. Actuators Mems VI 8763 (2013) 87630F.

[23] S.C. Moulzolf, D.J. Frankel, M.P. da Cunha, R.J. Lad, Microsyst. Technol. 20 (2014) 523.

[24] S.C. Moulzolf, D.J. Frankel, G.P. Bernhardt, B. Nugent, R.J. Lad, Smart Sens. Actuators MEMS V 8066 (2011) 806606.

[25] S.C. Moulzolf, R. Behanan, T. Pollard, R.J. Lad, M.P. da Cunha, 2013 IEEE Int. Ultrason. Symp. IUS (2013) 255.

[26] E.V. Vasil'eva, M.I. Zakharova, I.Y. Lazareva, Met. Sci. Heat Treat. 13 (1971) 372. 


\section{FIGURE CAPTIONS}

Fig. 1 Possible multi-layer film architectures for realizing conducting thin film electrodes that remain stable above $1000^{\circ} \mathrm{C}$ in air. The nanocomposite films can be designed to have either (a) phase inclusions or (b) interlayer phases to pin grain boundary motion at high temperature.

Fig. 2 Room temperature electrical conductivity of $\mathrm{Pt}_{83} \mathrm{Rh}_{17}-\mathrm{HfO}_{2}$ electrode films with different $10 \mathrm{~nm}$ thick adhesion layers deposited on (a) sapphire and (b) langasite substrates, after heating in air for $4 \mathrm{~h}$ at the indicated temperatures.

Fig. 3 Room temperature electrical conductivity of various Pt-alloy electrode films on (a) sapphire and (b) langasite substrates after heating in air for $4 \mathrm{~h}$ at the indicated temperatures. The electrode films were $150 \mathrm{~nm}$ thick with a $10 \mathrm{~nm} \mathrm{Zr}$ adhesion layer, and alloy compositions are given in atomic percent.

Fig. 4 Secondary electron images of (a) $\mathrm{Pt}_{85} \mathrm{Nb}_{15}$ (b) $\mathrm{Pt}_{83} \mathrm{Rh}_{17}$ (c) $\mathrm{Pt}_{96} \mathrm{Ta}_{4}$ films with a $\mathrm{Zr}$ adhesion layer on langasite substrates after heating in air for $4 \mathrm{~h}$ at $1000^{\circ} \mathrm{C}$.

Fig. 5 Electrical conductivity of Pt-Al films (black lines) and $\mathrm{Pt}-\mathrm{Al}_{2} \mathrm{O}_{3}$ films (red dotted lines) after heating in air for $4 \mathrm{~h}$ at the indicated temperatures. The solid data markers denote different Pt content, and the open data markers denote a second film with the same nominal composition as the film with the solid marker.

Fig. 6 Secondary electron images of (a) $\mathrm{Pt}_{93}-\mathrm{Al}_{2} \mathrm{O}_{3}$ film heated in air to $1050^{\circ} \mathrm{C}$; (b) $\mathrm{Pt}_{86}-\mathrm{Al}_{2} \mathrm{O}_{3}$ film heated in air to $1100^{\circ} \mathrm{C}$; and (c) $\mathrm{Pt}_{72}-\mathrm{Al}_{2} \mathrm{O}_{3}$ film heated in air to $1100^{\circ} \mathrm{C}$.

Fig. 7 Electrical conductivity of $\mathrm{Pt}_{83} \mathrm{Rh}_{17}$ films co-deposited with different grain boundary pinning materials after heating for $4 \mathrm{~h}$ in air at the indicated temperatures: (a) on sapphire substrates with $\mathrm{Zr}$ adhesion layer, and (b) on langasite substrates with $\mathrm{Zr}$ adhesion layer.

Fig. 8 Electrical conductivity of $\mathrm{Pt}-\mathrm{Ni}$ and $\mathrm{Pt}-\mathrm{Co}$ electrode films containing $\mathrm{Pt}_{84} \mathrm{Zr}_{16}$ pinning interlayers on sapphire substrates with $\mathrm{Zr}$ adhesion layer after heating for 4 hours in air at the indicated temperatures. Also shown is a $\mathrm{Pt}_{90} \mathrm{Ni}_{10}$ film with $\mathrm{ZrO}_{\mathrm{x}}$ interlayers.

Fig. 9 Secondary electron (left) and backscattered (right) images from (a) $\left[\mathrm{Pt}_{85} \mathrm{Co}_{15} / \mathrm{Pt}_{84} \mathrm{Zr}_{16}\right] \mathrm{x} 4$ and (b) $\left[\mathrm{Pt}_{90} \mathrm{Ni}_{10} / \mathrm{Pt}_{84} \mathrm{Zr}_{16}\right] \times 4$ multilayer films after heating in air for $4 \mathrm{~h}$ at $1100^{\circ} \mathrm{C}$.

Fig. 10 Electrical conductivity of $\mathrm{Pt}_{83} \mathrm{Rh}_{17}-\mathrm{ZrO}_{2}$ films on langasite substrates with $\mathrm{Zr}$ adhesion layer and different capping layers after heating in air for $4 \mathrm{~h}$ at the indicated temperatures. 


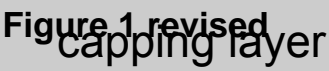

electrode with

pinning

INCLUSIONS

adhesion layer

interfacial barrier

substrate

(a)

\section{capping layer}

electrode with

pinning

INTERLAYERS

adhesion layer

interfacial barrier substrate

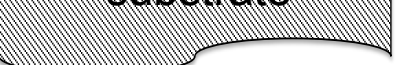

(b) 


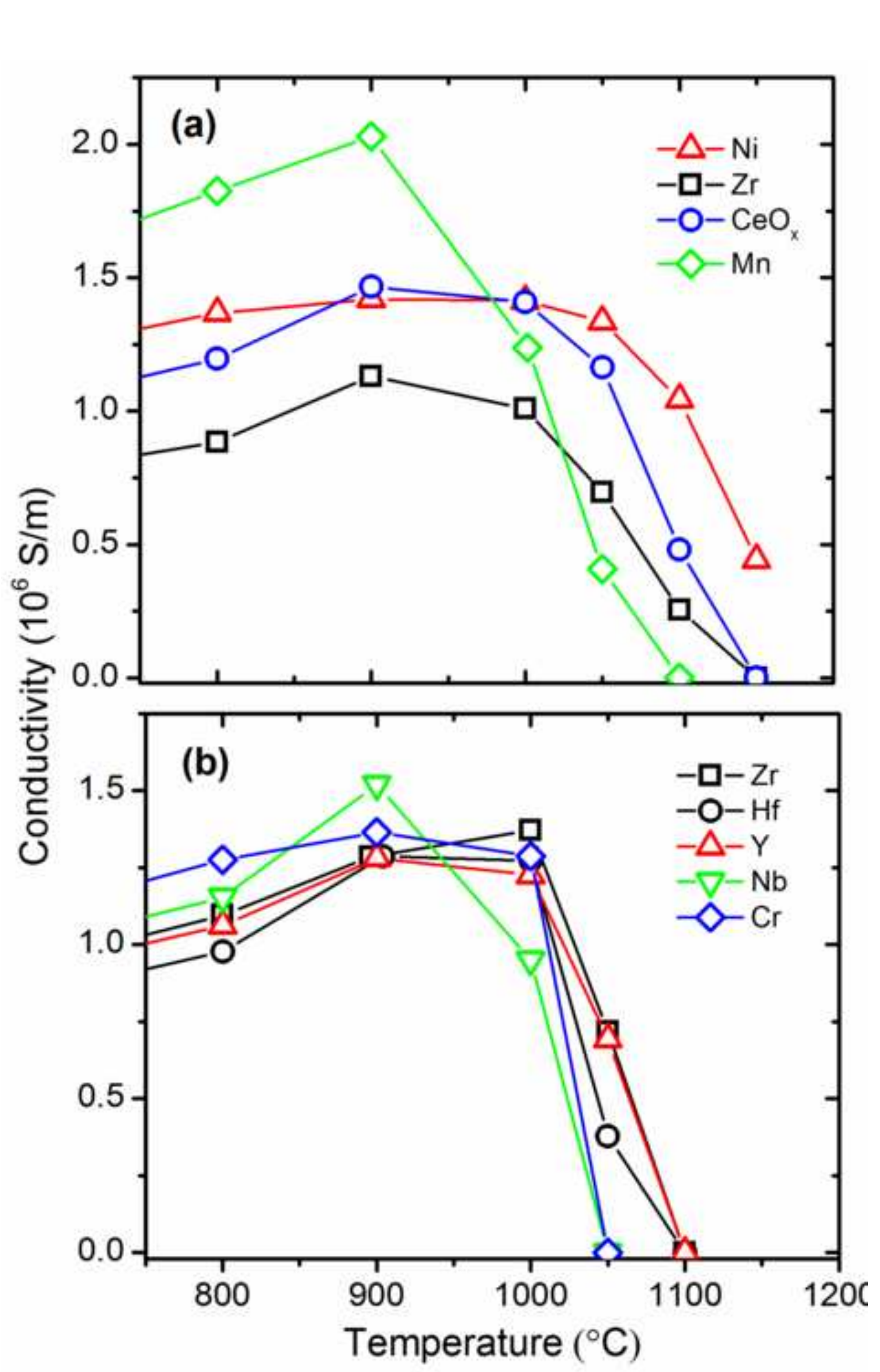

Figure 2

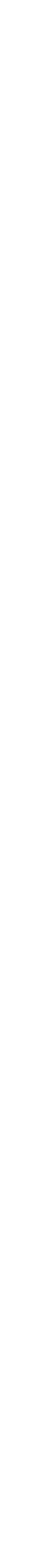




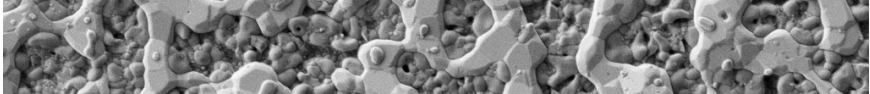
C50.

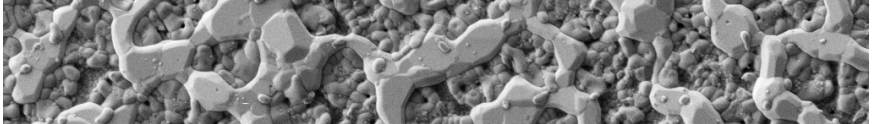

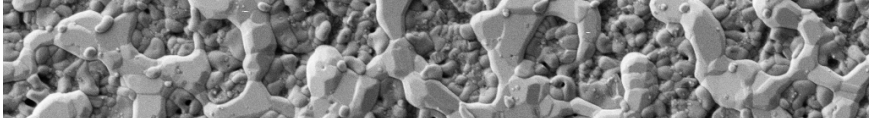

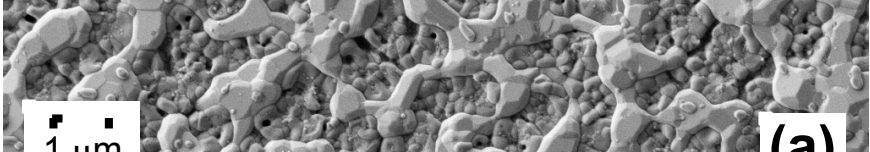
$i_{\mathrm{m}} \mathrm{C}$.

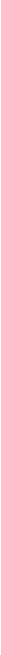

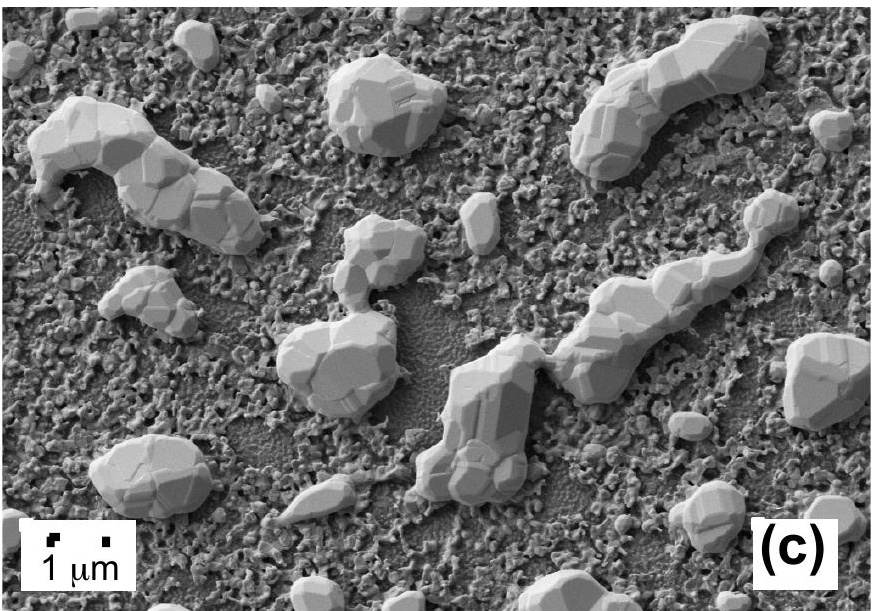




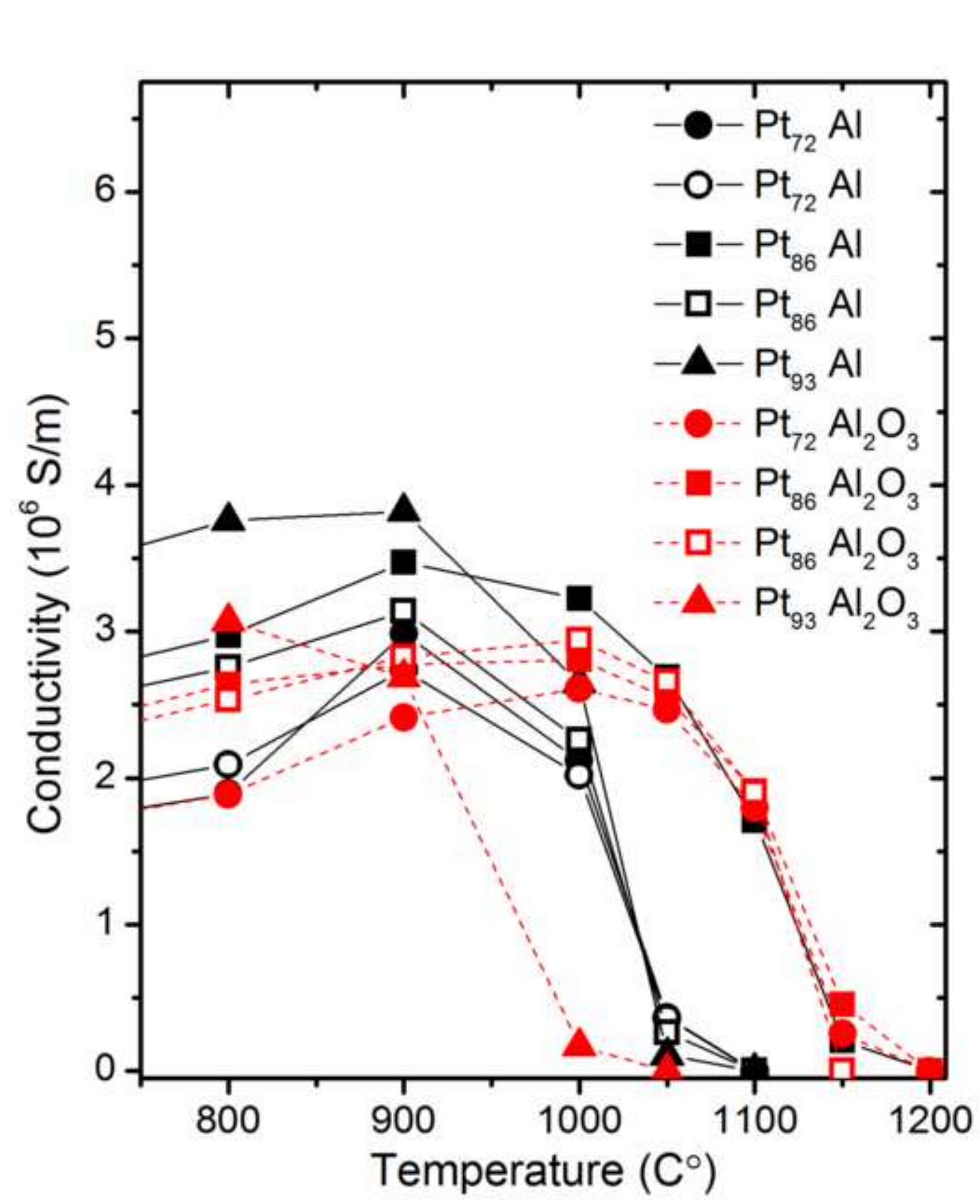

Figure 5

5

5

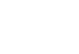
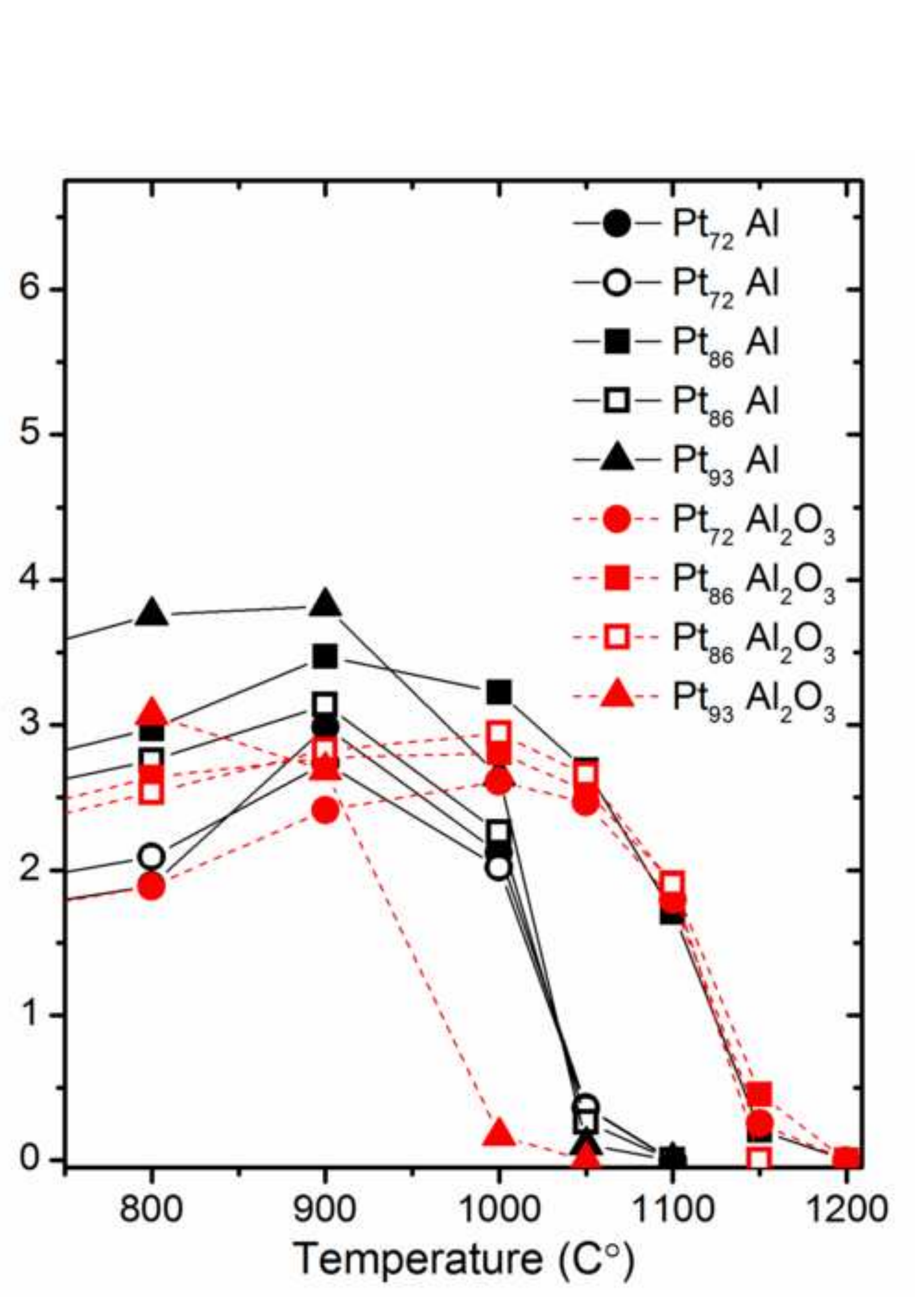


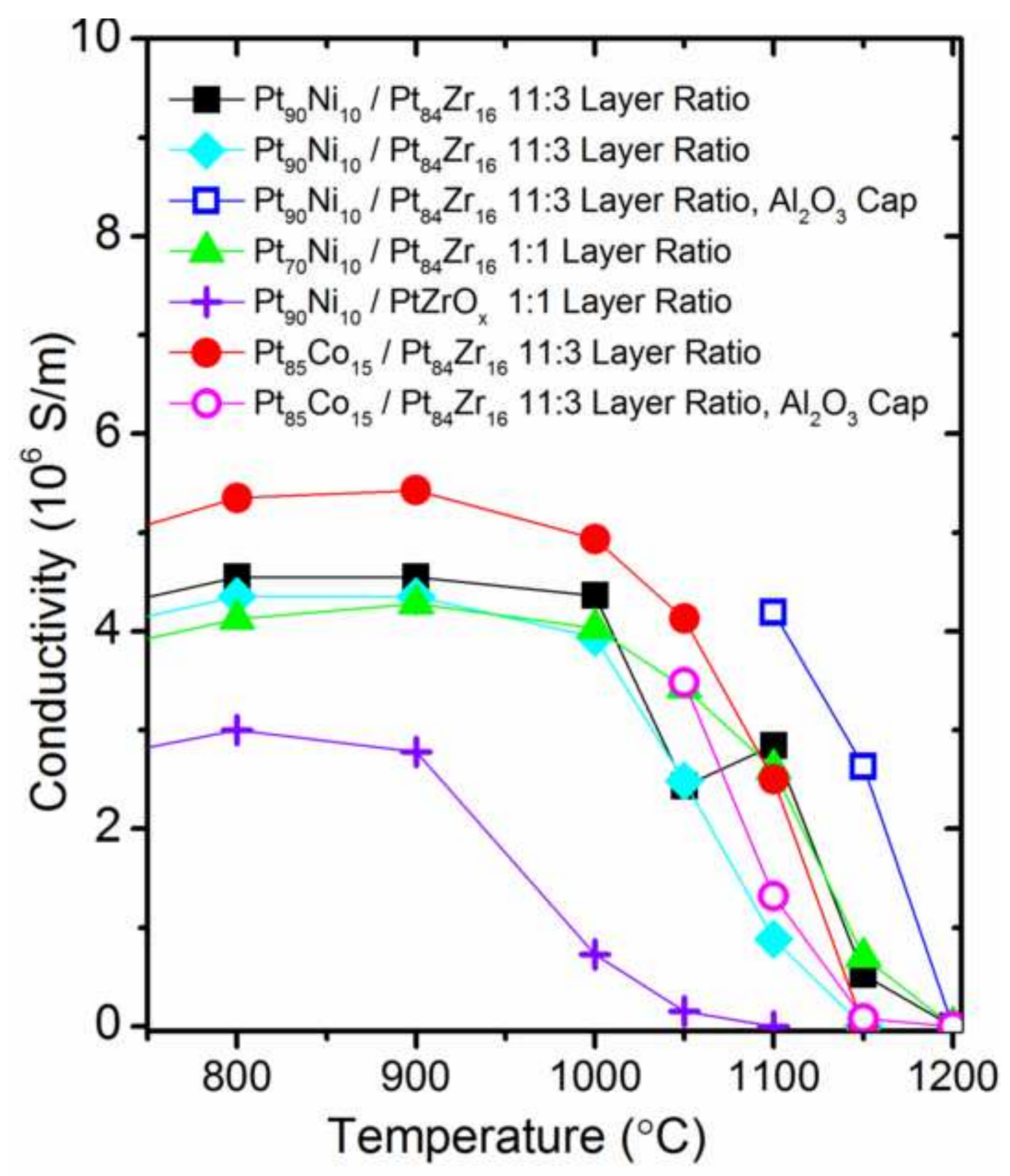

Figure 8 

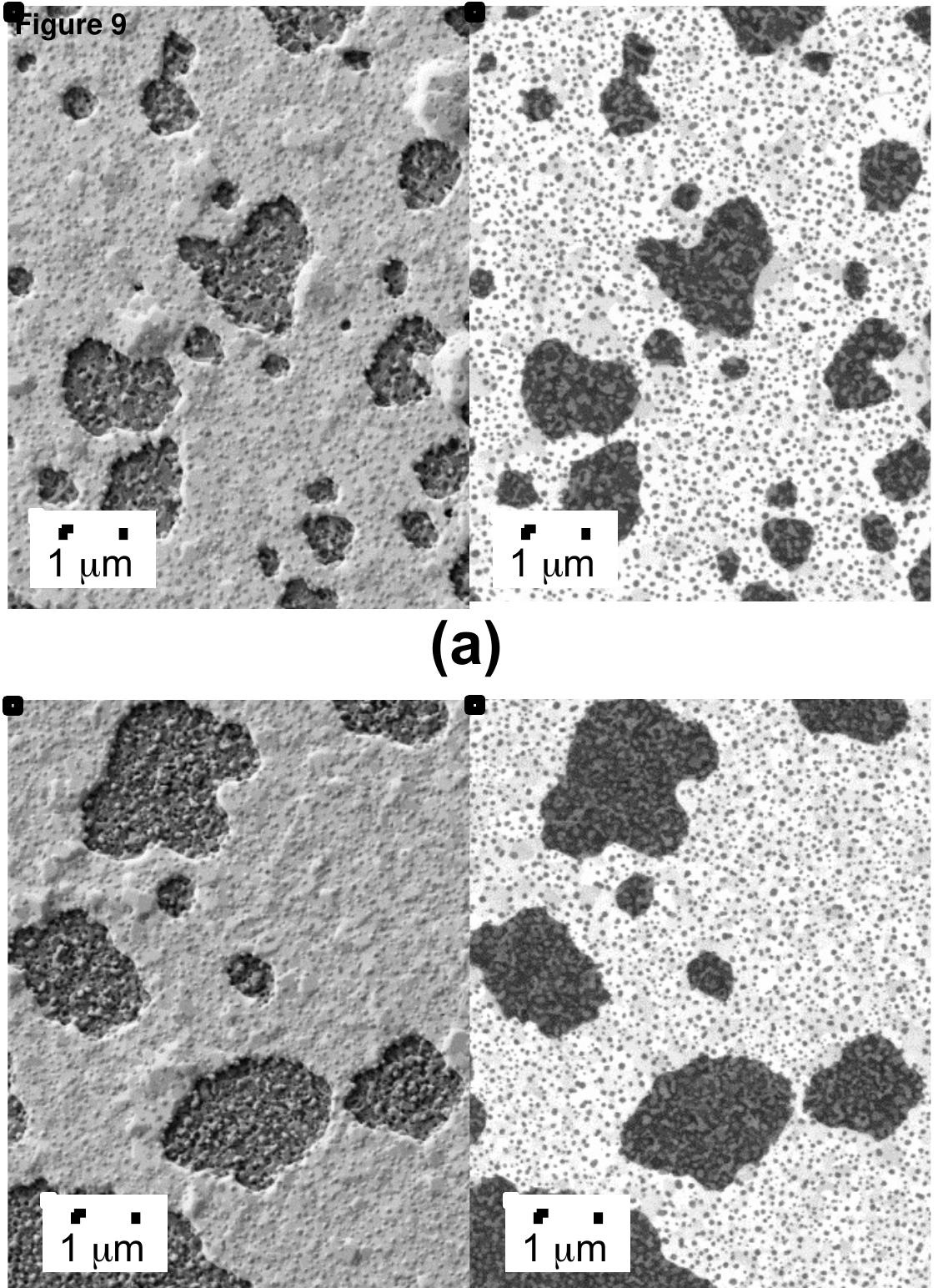


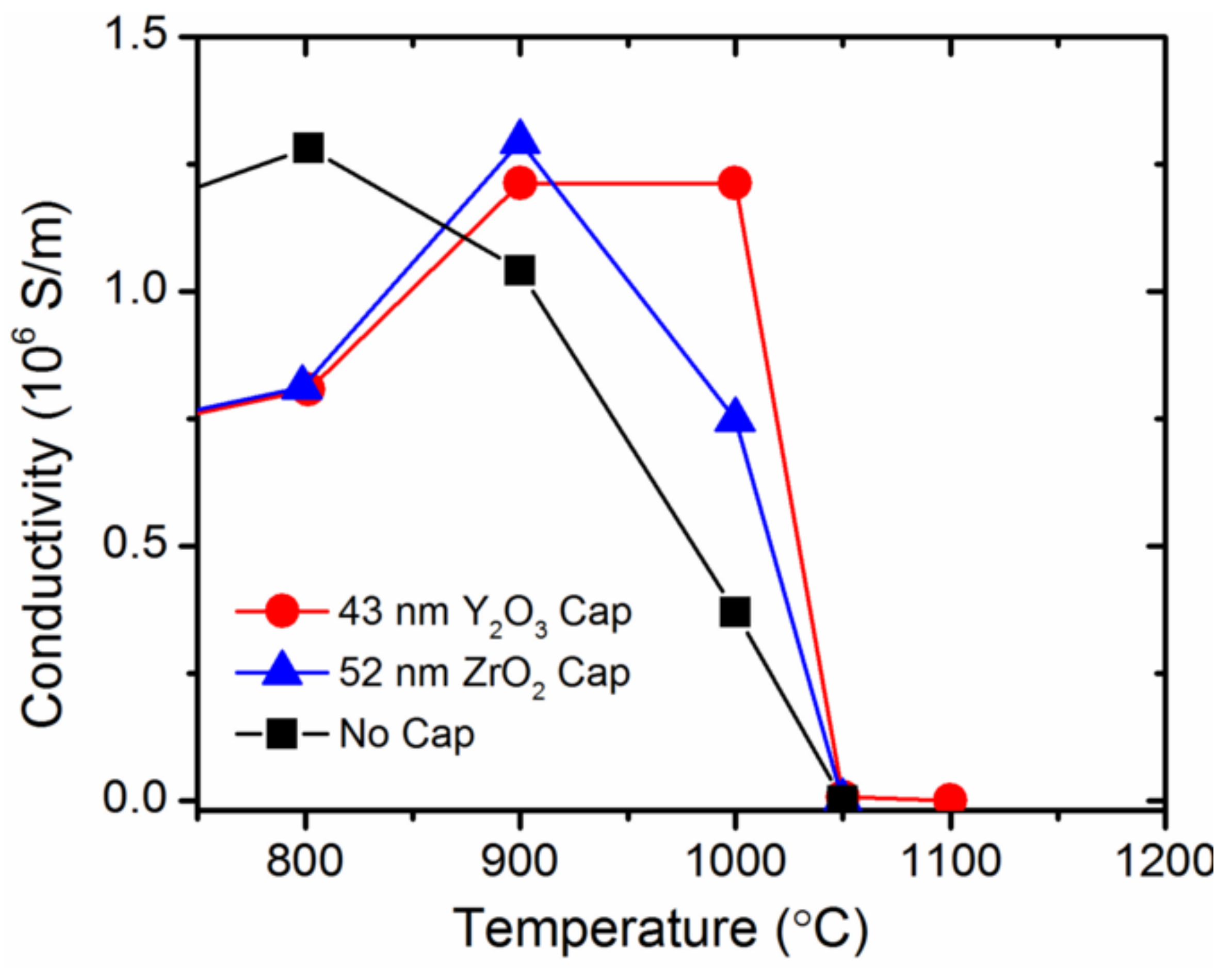

